\title{
Composite Shear Walls an Efficient Seismic Resistant System for Multi- Story Buildings
}

\section{Reslan N, Masri A and Machaka $\mathbf{M}^{\star}$}

Department of Civil Engineering, Beirut Arab University, Lebanon

\begin{abstract}
Steel-concrete composite systems have seen widespread use in recent decades because of the benefits achieved by merging the two materials. Due to their high stiffness and lateral load resistance, reinforced-concrete shear walls (RCSW) and steel-plate shear walls (SPSW) are considered ideal for resisting earthquake lateral loads in moderate and high-rise buildings. Recently, various schemes of composite shear walls (CSW) have been the focus of recent research. The objective of this paper is to investigate analytically the behaviour of composite shear walls as a lateral-load resisting system in comparison to RCSW. The investigation is performed on buildings with variable heights provided with either (RCSW) or (CSW). Three dimensional models for the case-study buildings are assembled using ETABS, computer software based on the Finite Element Method. The buildings are analyzed for static lateral forces computed by the Equivalent Static Load Method. Response spectra dynamic analyses, and dynamic time-history linear analyses using IZMIT earthquake record. Results are compared and interpreted so as the major findings include: First, to highlight on the structural characteristics and behaviour of composite shear walls as a seismic resistant system. Second, to compare between the structural behaviour of RCSW and CSW concerning their drifts, base shear and strength.
\end{abstract}

Keywords: Seismic; Composite; Shear Wall; Earthquake; Reinforced concrete

\section{Introduction}

The consequences of a severe earthquake as death casualties and property damages depend on the readiness of the country for such natural hazard. Countries notable for lack of suitable seismic design and construction usually suffers from high death counts due to moderate or strong earthquakes. Countries in the Middle East are seismically prone where they have a long history of damaging earthquakes. Majority of the buildings constructed in the region prior to the year 2000 were designed mainly for gravity loads, without considering the effect of seismic loads. In the last decade, governments began to recognize the risk and several regulations and codes have been put in practice for engineers to account for seismic design.

Lebanon is a good example, it is located along the $1000-\mathrm{km}$ fault propagating from the Red Sea to Turkey. During the past decade, a series of moderate earthquakes of approximately 4.5 degrees on Richter-scale occurred in Lebanon causing fear among people and minor property damage. Based on the seismic zone classification provided in the Uniform Building Code [1], Lebanon can be considered to be located in seismic zone (3).

Construction engineering in Lebanon depends on using reinforced concrete shear walls (RCSW) as a conventional seismic resistant system, and various configurations of RCSW are implemented in practice. Alternatively, new innovative and efficient seismic resistant systems are being widely used in countries like Japan, Canada and the United States. Among these systems are the steel-plate shear walls (SPSW) [1], and the composite shear walls (CSW) [2].

This paper will first highlights on the structural characteristics and behavior of the CSW as a seismic resistant system. Second, the behavior of the CSW will be investigated analytically and compared to that of the RCSW. The investigation is performed on buildings with variable heights provided with either RCSW or CSW. Three dimensional models for the case-study buildings are prepared using ETABS,[3]. The buildings are analyzed for static lateral forces computed by Equivalent
Static Load Method (UBC-1997), response spectral dynamic analysis and dynamic time-history linear analysis using the 1999-Izmit (Turkey) earthquake record. Comparison between the structural behaviors of RCSW and CSW, based on drifts and base shear levels, is presented.

\section{Composite Shear Walls}

The main components of a composite shear wall are a reinforced concrete shear wall, one or two steel plates, boundary steel beams and columns, and mechanical shear connectors. The steel plate is either attached on one or two sides of the RCSW, or encased within the RCSW. In both cases, shear connectors are welded to the steel plate in order to assure composite behavior. Various cross-sections for CSW are shown in Figure 1.

CSW are characterized by several advantages. Among these advantages are:

a. For the same shear capacity, a CSW will have a smaller thickness, less weight and most likely larger shear stiffness than a RCSW.

b. The smaller footprint of the CSW is attractive architecturally as more floor space is used.

c. The lesser the weight of CSW leads to lower seismic forces and smaller foundations.

d. The RC wall of the CSW can be either cast-in-place or precast.

*Corresponding author: Meheddene Machaka, Lecturer, Department of Civil Engineering, Beirut Arab University, Lebanon, Tel: +9613226441; E-mail: m.mashaka@bau.edu.lb

Received December 29, 2017; Accepted January 02, 2018; Published January 03, 2018

Citation: Reslan N, Masri A, Machaka M (2018) Composite Shear Walls an Efficient Seismic Resistant System for Multi-Story Buildings. J Steel Struct Constr 4: 140. doi: 10.4172/2472-0437.1000140

Copyright: ( 2018 Reslan N, et al. This is an open-access article distributed under the terms of the Creative Commons Attribution License, which permits unrestricted use, distribution, and reproduction in any medium, provided the original author and source are credited. 

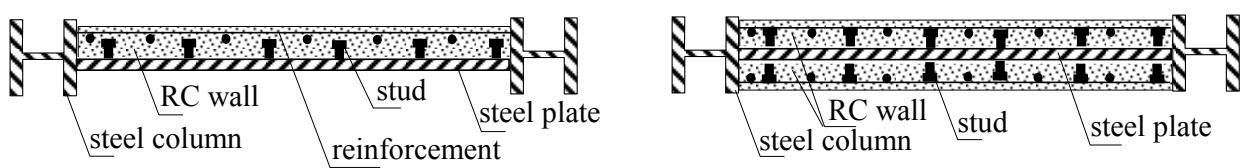

Figure 1: Cross Sections of Composite Shear Walls.

In the latter case, $\mathrm{RC}$ wall can be bolted to the steel plates at any convenient time during construction.

e. In a CSW, the RC wall restrains the steel plate and prevents its buckling before it yields in shear. Thus, the shear capacity of the steel plate can be significantly greater than its capacity to resist shear by the tension field action as in SPSW.

f. The RC wall provides sound and temperature insulation, in addition to fire proofing to the steel plates.

g. The damage of the CSW after a moderate or strong earthquake is repairable with minimal disturbance to its functionality.

\section{Description of the Case-Study Buildings}

\section{Buildings with RCSW}

Three categories representing low-rise, medium-rise and high-rise multi-story RC buildings are considered in the analysis. A typical plan area of $408 \mathrm{~m}^{2}$ is selected for an eight story, fourteen story and twenty story buildings. All buildings are provided with RC shear walls. Figure 2 shows a typical plan in all buildings. As shown, the walls are oriented in both directions. Walls $\left(\mathrm{P}_{1}-\mathrm{P}_{2}\right)$ resist in the long direction, and walls $\left(\mathrm{P}_{3}-\right.$ $\mathrm{P}_{4}-\mathrm{P}_{5}$ )resist in the short direction. The thickness of the walls ranged between $20 \mathrm{~cm}$ and $35 \mathrm{~cm}$ [4]. The concrete compressive strength is taken $30 \mathrm{MPa}$, while the reinforcing steel yield strength is $400 \mathrm{MPa}$.

\section{Buildings with CSW}

The RCSW are replaced by CSW having identical lengths, and in the same location and orientation mentioned above. Each panel of the CSW consists of two steel horizontal boundary elements (HBE), two steel vertical boundary elements (VBE), a steel plate, and the double layer of concrete encasement, one on each side of the plate as shown in Figure 1. The yield strength for the structural steel is taken $360 \mathrm{MPa}$. Details for the CSW are shown in Table 1.

Besides the overturning moments due to seismic loads, the VBE are designed to carry gravity loads while neglecting the contribution of the steel plate and the surrounding concrete. This is essential to ensure that the structural framing system have a sufficient capacity to support the gravity loads during an earthquake, during which the plate experiences buckling due to the development of its tension field action. In addition, the VBE provide an anchor point for tension field action of the steel plate and bearing element for diagonal compression of the concrete wall [5].

\section{Modeling of the CSW}

As the steel plate of a CSW buckles in shear due to lateral deformations, a diagonal tension field develops in the plate where additional lateral forces can be resisted by the wall. Based on an elastic strain energy formulation, Timler and Kulak (1983) derived the following equation for the inclination angle $(\alpha)$ of the tension field in a CSW.

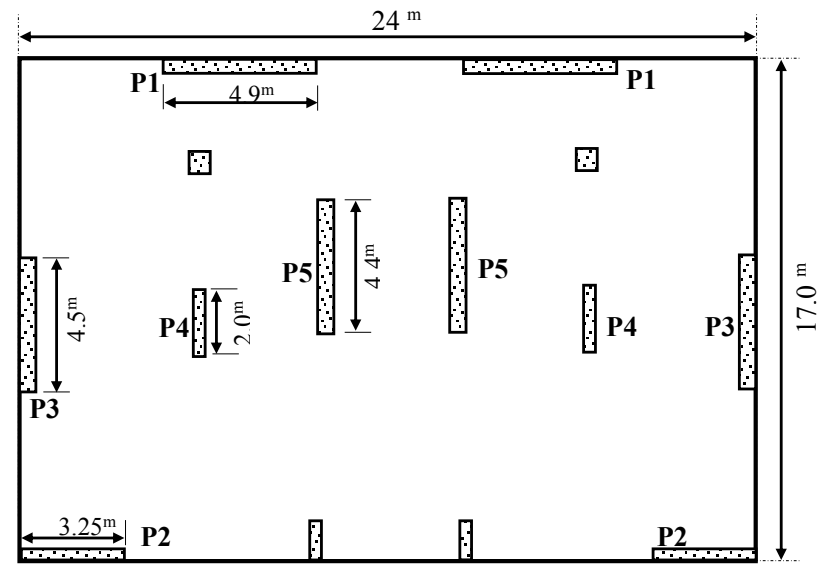

Figure 2: Typical Plan for Buildings with RC Walls.

\begin{tabular}{|c|c|c|c|c|c|c|}
\hline \multirow{2}{*}{ Pier } & \multicolumn{2}{|c|}{ 8-Story Building } & \multicolumn{2}{c|}{ 14-Story Building } & \multicolumn{2}{c|}{ 20-Story Building } \\
\cline { 2 - 7 } & HBE & VBE & HBE & VBE & HBE & VBE \\
\hline $\mathbf{P}_{\mathbf{1}}$ & HE180B & HE300B & HE240B & HE450B & HE340B & HE600B \\
\hline $\mathbf{P}_{2}$ & HE140A & HE140A & HE200A & HE200A & HE240B & HE240B \\
\hline $\mathbf{P}_{3}$ & HE180B & HE300B & HE240B & HE450B & HE340B & HE600B \\
\hline $\mathbf{P}_{\mathbf{4}}$ & HE140A & HE140A & HE200A & HE200A & HE240B & HE240B \\
\hline $\mathbf{P}_{\mathbf{5}}$ & HE180B & HE300B & HE240B & HE450B & HE340B & HE600B \\
\hline
\end{tabular}

Table 1: Details of the Composite Shear Walls.

$a=\tan ^{-1} \sqrt[4]{\frac{1+\frac{L}{2 A_{c}}}{1+\operatorname{th}\left(\frac{1}{A_{b}}+\frac{h^{3}}{360 I_{c} L}\right)}}$

Where:

t: Thickness of the steel plate

h: Clear height of the story

L: Bay width

$I_{c}$ : Moment of inertia of the vertical boundary element

A : Cross-sectional area of the vertical boundary element

$A_{b}$ : Cross-sectional area of the horizontal boundary element.

For the VBE, it has been recommended by Montgomery and Medhekar (2001) that the moment of inertia (I $)$ should be:

$I_{c} \geq \frac{0.00307 t_{w} h^{4}}{L}$

Accordingly, the values for the angle ( $\alpha$ ) for all CSW are tabulated in Table 2 .

The flexural stiffness of the HBE was excluded in the derivation because the opposing tension fields that develop above and below these intermediate horizontal members almost cancel out and induce little 
significant flexure there. Using the inclination angle ( $\alpha$ ), an analytical strip model developed by Thorburn et al. (1983), and refined by Timler and Kulak (1983) is used [6].

\section{Three Dimensional Models}

Three dimensional computer models for the buildings are assembled using the Structural Analysis Program ETABS, [3] (Figure 3). Frame elements are used for modeling of HBE and VBE. In this model, the CSW is considered as a series of strips modelled by pin ended truss members. Figure 4 shows the dimensions of each strip for the composite cross-section, and the equivalent transformed steel cross-

\begin{tabular}{|c|c|}
\hline Pier & Angle ( $\mathbf{\alpha})$ \\
\hline $\mathrm{P}_{1}$ & $44.68^{\circ}$ \\
\hline $\mathrm{P}_{2}$ & $40.74^{\circ}$ \\
\hline $\mathrm{P}_{3}$ & $45.00^{\circ}$ \\
\hline $\mathrm{P}_{4}$ & $38.65^{\circ}$ \\
\hline $\mathrm{P}_{5}$ & $45.00^{\circ}$ \\
\hline
\end{tabular}

Table 2: Inclination Angle $(\alpha)$ of the Tension Field in a CSW.

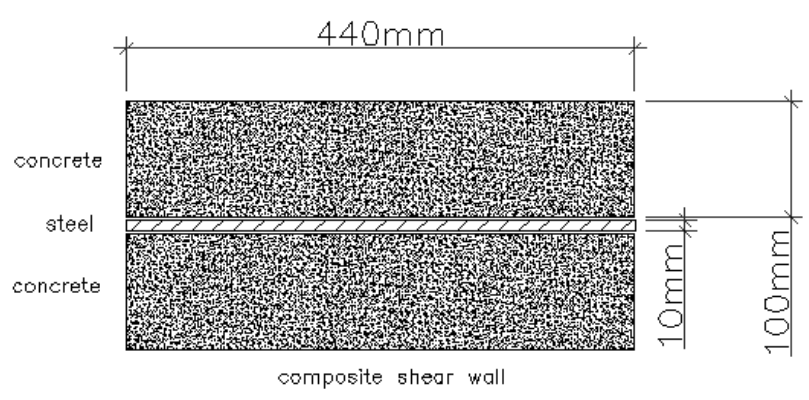

Figure 3: Composite Cross-Section of Composite Shear Wall Strip.

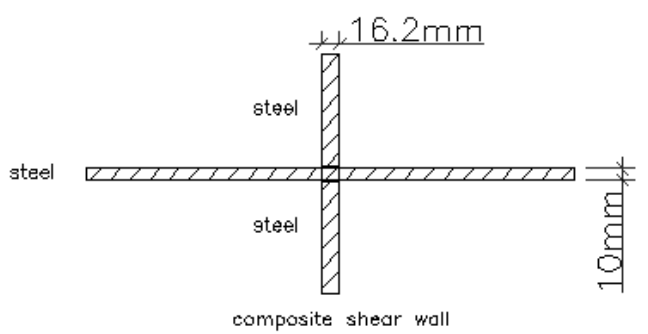

Figure 4: Transformed Steel Cross-Section of Details of Composite Shear Wall Strip. section. Rectangular finite shell elements are used for modeling of the slabs, RCSW and CSW. To account for the cracked section properties in the RCSW, the geometric properties of the wall are reduced. The crosssectional area and the moment of inertia are reduced to half and onethird respectively.

Structural analysis for all models is carried for both dead loads and seismic lateral loads established from either the UBC 1997 equivalent static forces, UBC response spectrum functions, or the time-history dynamic analysis. The 1999 Izmit-earthquake record is used for the time-history dynamic analysis. Such analysis provides broad understanding about the behavior of the structure when subjected to earthquakes of similar input, mainly time duration and acceleration magnitude. Figure 5 shows The peak ground acceleration (PGA) for this record is about $300 \mathrm{~cm} / \mathrm{sec}^{2}$, which corresponds to a $0.3 \mathrm{~g}$ value. The time duration of this earthquake was 57 seconds, but the dynamic analysis is performed for the first 40 seconds of the record.

\section{Response of the 8-Story Buildings}

Figure 6 shows a comparison of the base shear values for the 8 -story building provided by RCSW or CSW and subjected to static lateral loads, response spectra dynamic loads, or time-history dynamic loads in both directions. The maximum resisted base shear in the building with RCSW in the X and Y directions is 470 tons for (STAT-X) analysis and 518 tons for (STAT-Y) analysis, respectively [7]. Whereas, the maximum resisted base shear in the building with CSW in the two directions is 188 tons for (HIST-X) and 271 tons for (STAT-Y), respectively. A significant reduction in the base shear (46\%) is observed in both static lateral loads and response spectra dynamic loads analyses mainly due to the lightness of the CSW.

Figure 7 shows the story drifts resulting from the $\mathrm{X}$-direction loads in both types of buildings. The maximum drift in the building with RCSW is at the fifth story with a value of $1.44 \%$ for (RESP-X) analysis. Whereas, the maximum drift in the building with CSW is at the fourth story with a value of $1.57 \%$ for (HIST-X) analysis. Both drift values did not exceed the permissible value recommended in UBC 1997.

The story-shear distribution to (HIST-X) analysis for both buildings is shown in Figure 8. The maximum attained base shear in the building with RCSW 223 tons, while the maximum base shear in the building with CSW is 167 tons which is $19.65 \%$ less than that of the RCSW building.

\section{Response of the 14-Story Buildings}

Figure 9 shows a comparison of the base shear values for the

\section{Izmit Record}

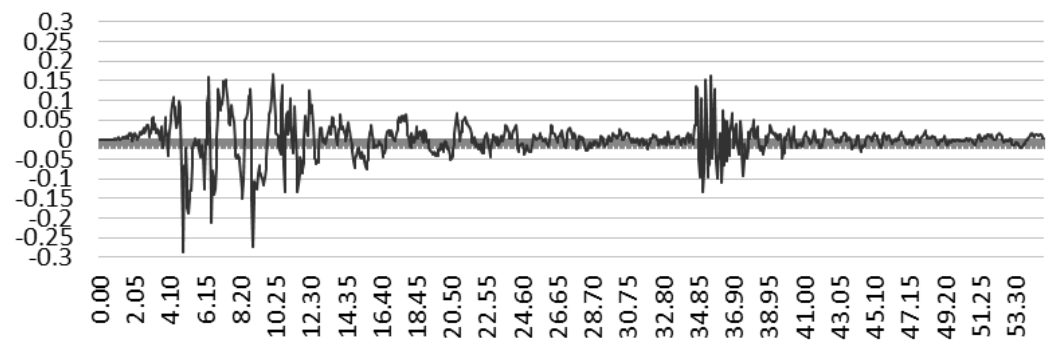

-Ground acceleration ( $\mathrm{g}$ )

Figure 5: Details of Original Izmit record (PGA=0.28497). 


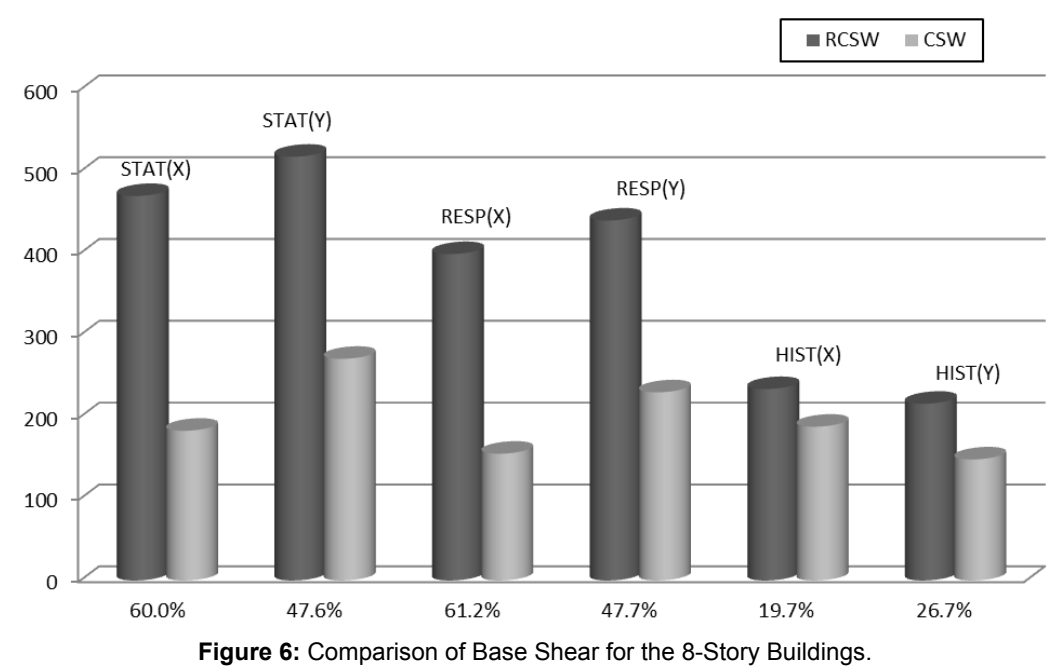

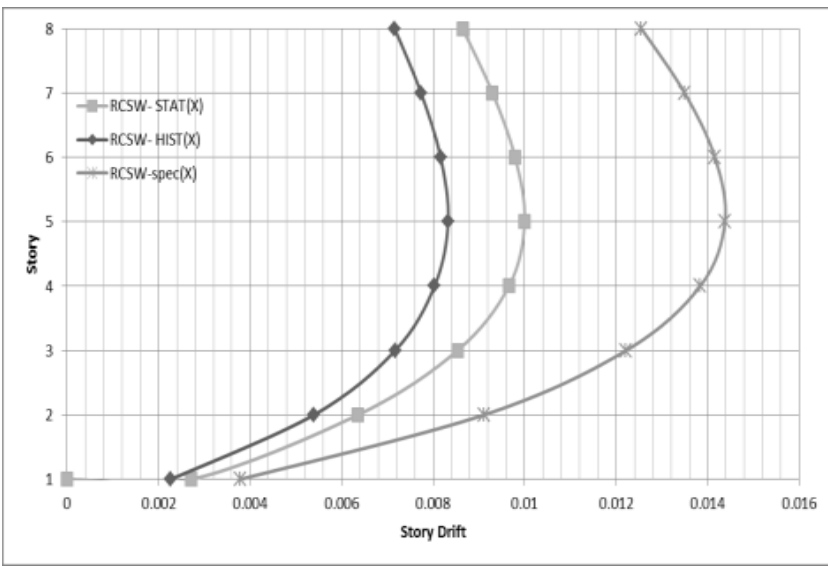

a. RCSW

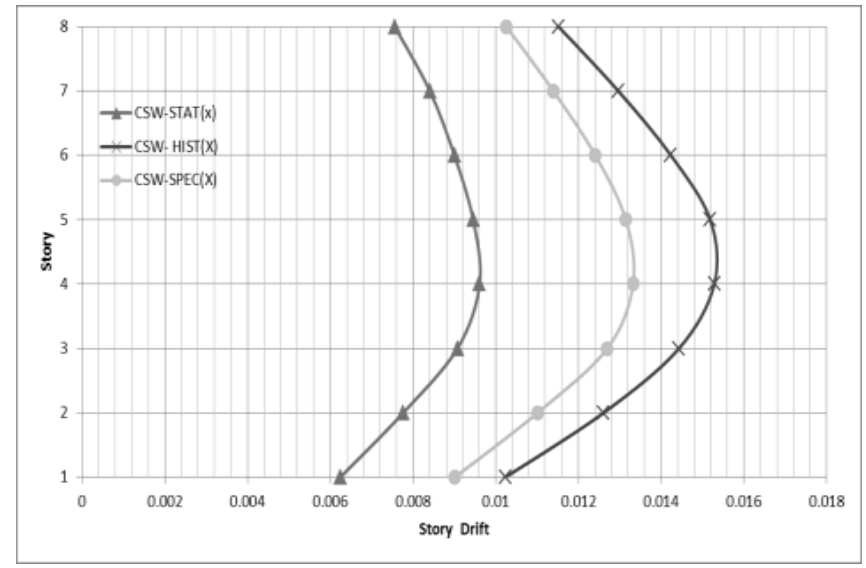

b. CSSW

Figure 7: Story Drifts for the 8-Story Buildings.

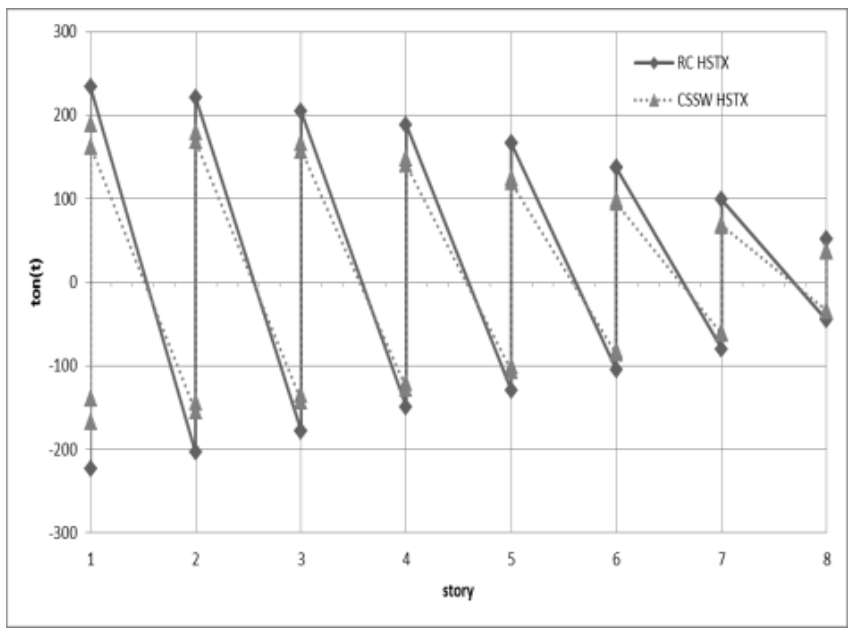

Figure 8: Story Shear and Story Drift Distribution due to HIST-X Analysis.

14-story building provided by RCSW or CSW and subjected to three types of seismic forces (as discussed above) in both directions. The maximum resisted base shear in the building with RCSW in the $\mathrm{X}$ and Y directions is 562 tons and 556 tons for (STAT-X) and (STAT-Y) 
Citation: Reslan N, Masri A, Machaka M (2018) Composite Shear Walls an Efficient Seismic Resistant System for Multi-Story Buildings. J Steel Struct Constr 4: 140. doi: 10.4172/2472-0437.1000140

Page 5 of 7

analyses, respectively. Whereas, the maximum resisted base shear in the building with CSW in the two directions is 270 tons for (STAT-X) analysis and 268 tons for (STAT-Y) analysis, respectively [8].

Figure 10 shows the story drifts resulting from the $\mathrm{X}$-direction loads in both types of buildings. The maximum drift in the building with RCSW is at the seventh story with a value of $1.90 \%$ for (RESP-X) analysis. Whereas, the maximum drift in the building with CSW is at the sixth story with a value of $1.95 \%$ for (RESP-X) analysis. Both drift values did not exceed the permissible value recommended in UBC 1997.

The story-shear and drift distributions for both buildings due to (STAT-X) analysis are shown in Figure 11. The maximum attained base

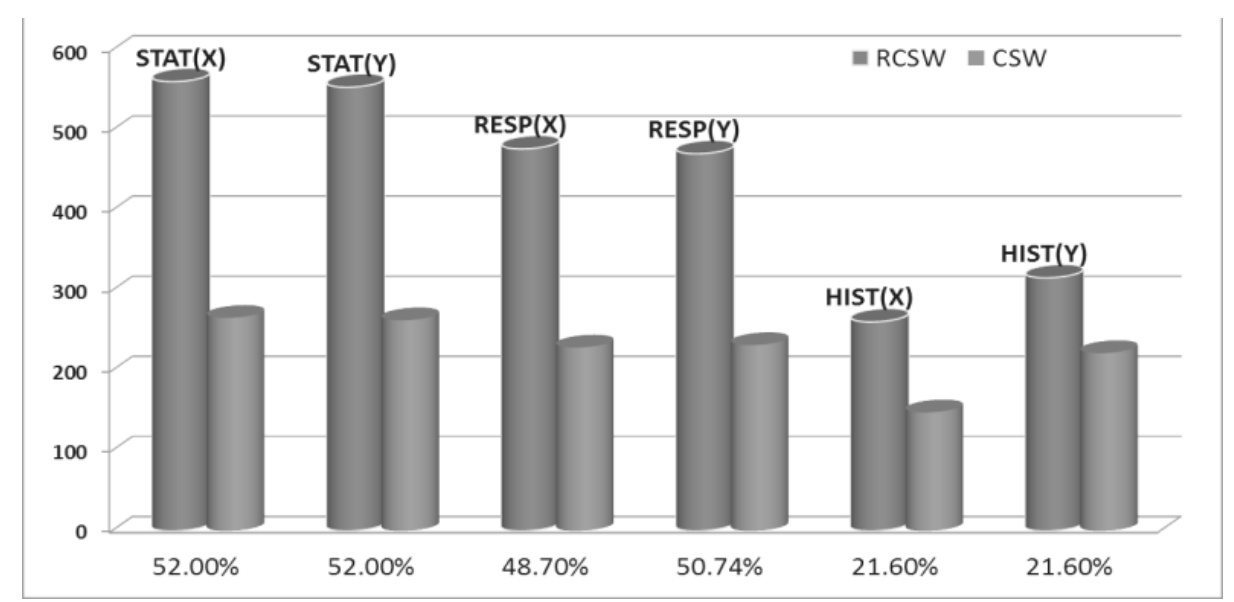

Figure 9: Comparison of Base Shear for 14-Story Buildings.

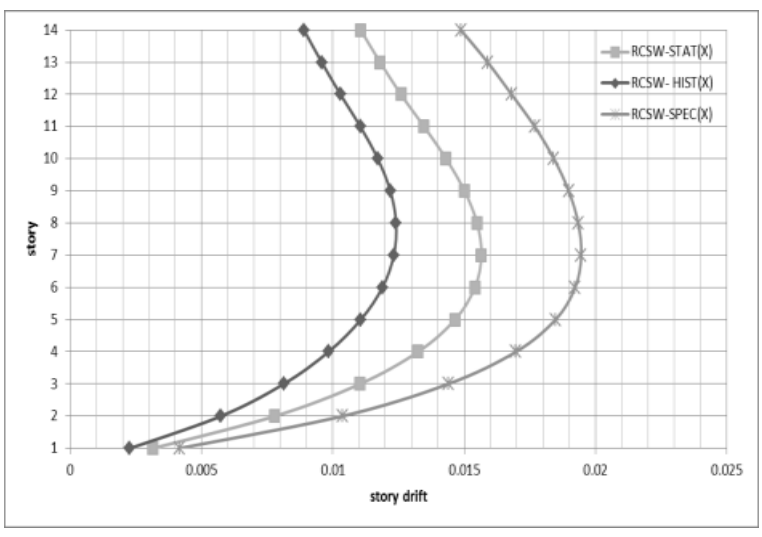

a. RCSW

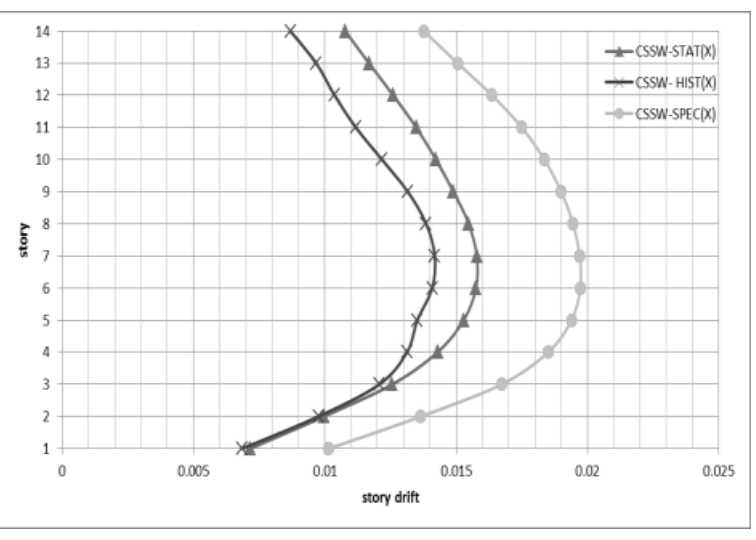

b. CSSW

Figure 10: Story Drifts for the 14-Story Buildings.

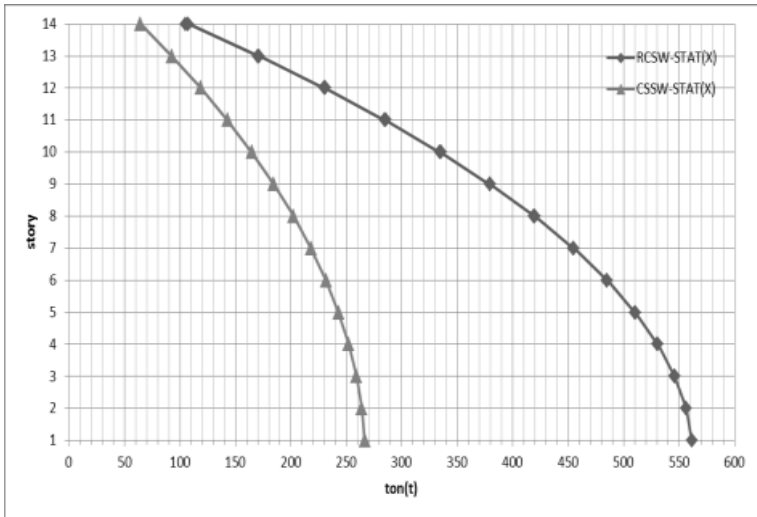

a. RCSW

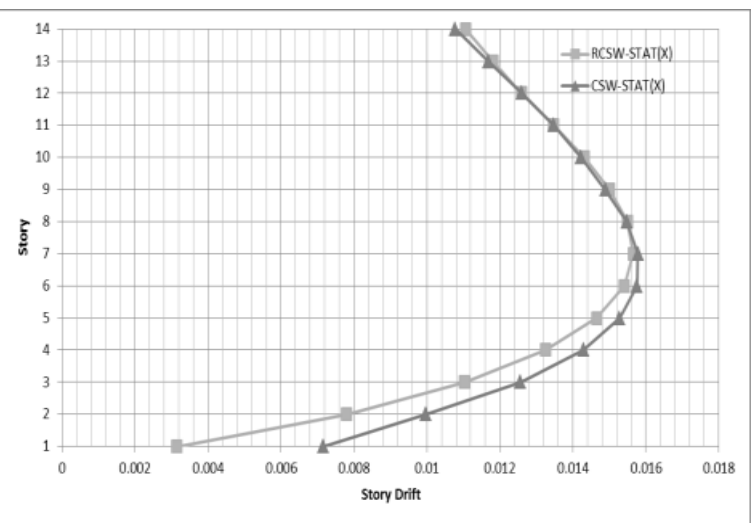

b. CSSW

Figure 11: Story Shear and Drift for the 14-Story Buildings. 
Citation: Reslan N, Masri A, Machaka M (2018) Composite Shear Walls an Efficient Seismic Resistant System for Multi-Story Buildings. J Steel Struct Constr 4: 140. doi: 10.4172/2472-0437.1000140

Page 6 of 7

shear in the building with RCSW is 561 tons, while the maximum base shear in the building with CSW is 266 tons which is $52 \%$ less than that of the RCSW building.

\section{Response of the 20-Story Buildings}

A comparison of the base shear values for the 20-story building provided by RCSW or CSW and subjected to static lateral loads, response spectra dynamic loads, or time-history dynamic loads in both directions is shown in Figure 12. The maximum resisted base shear in the building with RCSW in the $\mathrm{X}$ and $\mathrm{Y}$ directions is 634 tons for (STAT-X) analysis and 620 tons for (STAT-Y) analysis, respectively $[9,10]$. Whereas, the maximum resisted base shear in the building with CSW in the two directions is 396 tons for (STAT-X) and 384 tons for (STAT-Y), respectively. As seen, a significant reduction in the base shear is observed in both static and response spectra dynamic loads analyses mainly due to the lightness of the CSW.

Figure 13 shows the story drifts resulting from the Y-direction loads in both types of buildings. The maximum drift in the building with RCSW is at the tenth story with a value of $1.15 \%$ for (STAT-Y) analysis. Whereas, the maximum drift in the building with CSW is at the eleventh story with a value of $1.46 \%$ for (STAT-Y) analysis. Both drift values did not exceed the permissible value recommended in UBC 1997 [11].
The story-shear and drift distributions for both buildings due to (RESP-Y) analysis are shown in Figure 14. The maximum attained base shear in the building with RCSW is 542 tons, while the maximum base shear in the building with CSW is 324 tons which is $40 \%$ less than that of the RCSW building.

\section{Conclusions}

Providing RC buildings with composite shear walls instead of RC shear walls is a very efficient and attractive structural decision to be implemented in regions vulnerable to earthquakes, due to the following advantages:

1. A significant reduction in the total dead load of the building due to less thickness of the steel wall compared to the RC shear wall. Consequently, the story-shear forces and base shear are reduced by $46 \%$ in the eight-story buildings, and $38 \%$ in the twenty-story buildings.

2. The inelastic drifts in the buildings with composite shear walls are higher than those in the buildings with RC shear walls by $9 \%$ in the eight-story buildings, and $26 \%$ in the twenty-story buildings.

3. The stiffness of the building with composite shear walls is higher because the rigidity of steel walls (EI) is greater than that of RC walls due to cracking and less modulus of elasticity.

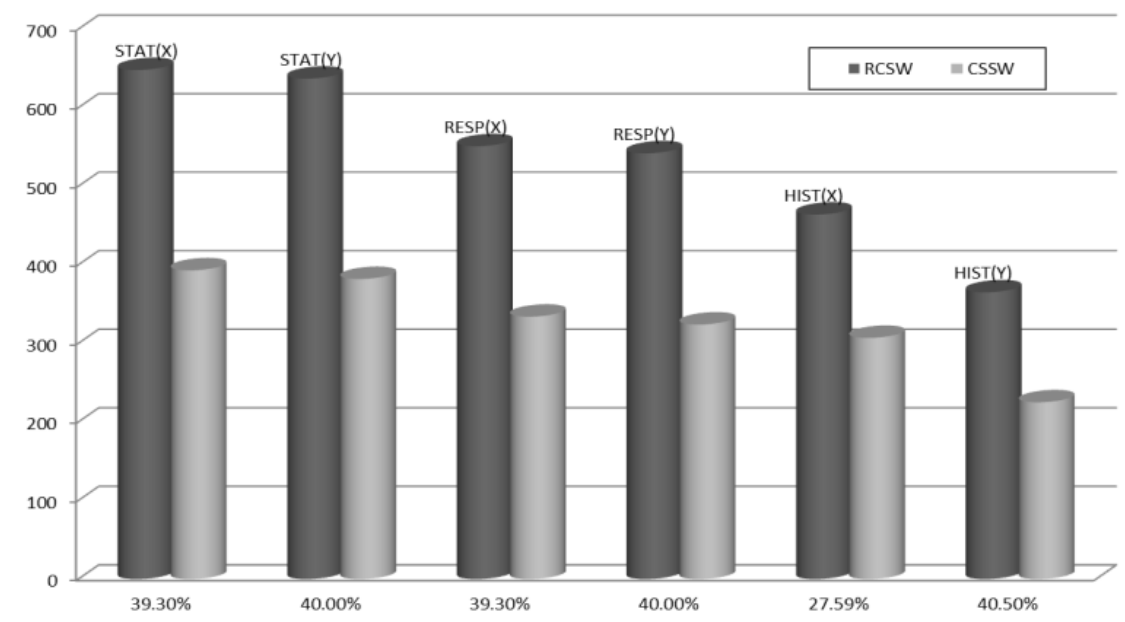

Figure 12: Comparison of Base Shear for 20-Story Buildings.
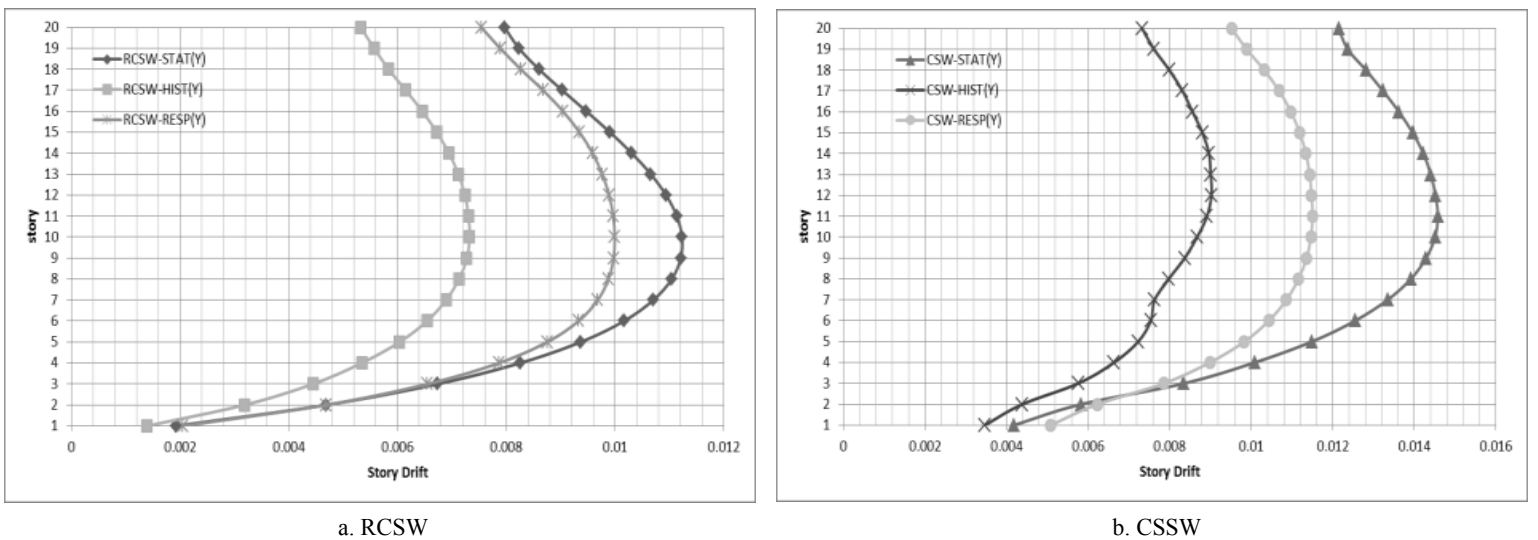

Figure 13: Story Drifts for the 20-Story Buildings. 
Citation: Reslan N, Masri A, Machaka M (2018) Composite Shear Walls an Efficient Seismic Resistant System for Multi-Story Buildings. J Steel Struct Constr 4: 140. doi: 10.4172/2472-0437.1000140

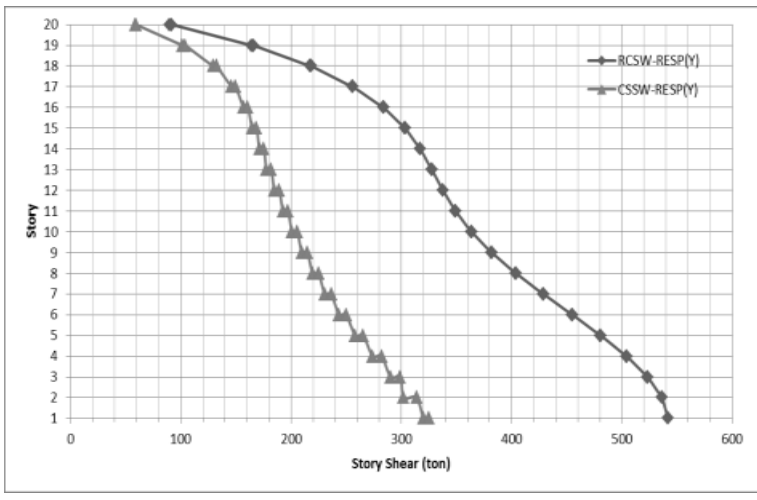

a. RCSW

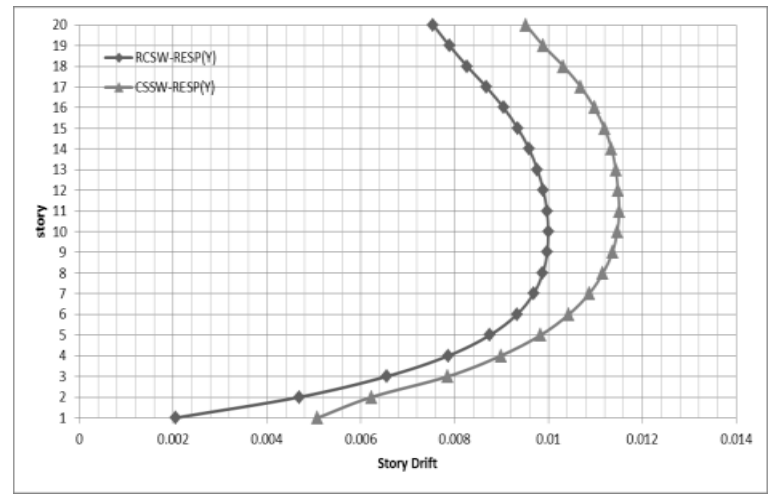

b. CSSW

Figure 14: Story Shear and Drift for the 20-Story Buildings.

4. Composite shear walls are characterized being of higher ductility than RC shear walls with higher energy of dissipation, a basic requirement for seismic design.

\section{References}

1. Uniform Building Code UBC (1997) California, USA.

2. Astaneh-Asl A (2001) Seismic Behavior and Design of Steel Shear Walls. Department of Civil and Env. Eng. Univ. of California, Berkeley.

3. Astaneh-AsI A (2002) Seismic Behaviour and Design of Composite Shear Walls. Structural Steel Educational Council.

4. Computers and Structures Inc. Structural Analysis Program ETABS.

5. Mathews FL, Davies GAO, Hitchings D, Soutis C (2000) Finite Element Modelling of Composite Materials \& Structures. Woodhead Publishing Ltd.
6. Naeim F (2001) The Seismic Design Handbook. Kluwer Academic Publishers.

7. Williams A (1999) Seismic Design of Buildings \& Bridges for Civil and Structural Engineers. ICBO, $3^{\text {rd }}$ Edition.

8. Smith SB, Coull A (1991) Tall building structures: Analysis and Design. John Wiley \& sons, Inc.

9. Johnson RP (2004) Composite Structures of Steel and Concrete. Blackwell Publications.

10. Oehlers DJ, Bradford MA (1999) Elementary Behaviour of Composite Steel and Concrete Structural Members.

11. Basha H, Temsah Y, Masri A, Machaka M (2010) Optimization of Wall-Frame Resisting System in Buildings Subjected to Seismic Loads. Seventh Alexandria International Conference on Structural and Geotechnical Engineering. 